\title{
Chapter 11 \\ Local and Scientific Knowledge \\ Integration for Multi-risk Assessment \\ in Rural Niger
}

\author{
Maurizio Tiepolo and Sarah Braccio
}

\begin{abstract}
In the rural Tropics, the participatory risk assessment, based on local knowledge only, is very widespread. This practice is appropriate for hazard identification and for raising the awareness of local communities in relation to the importance of risk reduction, but it is still imprecise in determining risk level, ranking and treatment in a context of climate change, activities in which technical knowledge is unavoidable. Integration of local and technical-scientific knowledge within the framework of an encoded risk assessment method (ISO 31010), could favour more effective decision making with regard to risk reduction. The aim of this chapter is to verify the applicability of a multi-risk local assessment-MLA which combines local knowledge (participatory workshop, transect walk, hazard and resource mapping, disaster historical profile) and scientific knowledge (climate downscaling modelling, hazard probability and scenarios, potential damages, residual risk). The test is carried out in two villages of the Western Niger, particularly exposed to flooding and agricultural drought. The risk (hazard probability * potential damages) is identified, analysed (level of risk) and evaluated (residual risk, adaptation measures compared with potential damage costs). The MLA is feasible. The two villages, while bordering on one another, have a different risk ranking. Depending on the village, the risk treatment could reduce the risk level to 17 and to $41 \%$ of the current risk, with costs equating to 34 and $28 \%$ of the respective potential damages.
\end{abstract}

Keywords Climate change - Local and scientific knowledge $\cdot$ Multirisk $\cdot$ Risk analysis · Risk evaluation · Flood · Drought • Gothèye • Niger

Maurizio Tiepolo is author of all the sections with the only exception of 11.3.3, written by Sarah Braccio.

M. Tiepolo $(\bowtie) \cdot$ S. Braccio

DIST, Politecnico and University of Turin, Viale Mattioli 39, 10125 Turin, Italy

e-mail: maurizio.tiepolo@polito.it

S. Braccio

e-mail: sarah.braccio@polito.it

(C) The Author(s) 2017

M. Tiepolo et al. (eds.), Renewing Local Planning to Face Climate

Change in the Tropics, Green Energy and Technology,

DOI 10.1007/978-3-319-59096-7_11 


\subsection{Introduction}

The risk assessment is the overall process of risk identification, analysis and evaluation. Identification consists in finding, recognising and describing risks. The analysis allows us to comprehend the nature and determine the level of risk, expressed in terms of a combination of the consequences of an event and the associated likelihood of occurrence. Evaluation determines whether the risk is acceptable or tolerable (ISO 2009).

In the Tropics, local risk assessment took hold after the World conference on natural disaster reduction (Yokohama 1994), which indicates it as a required step in disaster reduction (UNDHA 1994). NGOs and multi-bilateral donors conformed the risk assessment to the participatory rural appraisal-PRA of Chambers (1992), which used different tools, including community maps, gradually evolved into participated GIS-pGIS and 3D participated modelling (Rambaldi 2010).

The second Conference on disaster risk reduction (Hyogo 2004) recommended the integration of disaster risk reduction into plans. The first risk assessment experiences were consolidated in the Community Risk Assessment-CRA, introduced by the Provention consortium, a global coalition of governments, international organizations, academic institutions, private sector and civil societies organizations (Abarquez and Murshed 2004), and in the Vulnerability and Capacity Assessment-VCA of the International Federation of Red Cross and Red Crescent Societies (IFRCRC 2006; Van Aalst et al. 2008), recently adapted to consider climate change (IFRCRC 2014). Today, in the Tropics, a growing number of countries integrates risk analysis into local development plans: Madagascar and South Africa (since 2002), Philippines (since 2008), Mexico and Nepal (since 2011), Colombia and Honduras (since 2013), Nicaragua (Faling et al. 2012; Florano 2015; GoN 2011; Guardiola et al. 2013; Ruiz Rivera et al. 2015; Vermaak et al. 2004).

The recommendations of the Fourth African Regional Platform for Disaster Risk Reduction to quantify risk, standardize risk assessments and create and strengthen risk databases (UNISDR 2013: 55) are incorporated into certain pilot examples of risk analysis at meso-scale (Pezzoli and Ponte 2016; Tiepolo and Braccio 2016b) and at micro-scale (Ponte 2014, Tiepolo and Braccio 2016a).

The 3rd World Conference on DRR (Sendai 2015) eliminated every reserve regarding the integration of scientific and local knowledge (UN 2015: 11) on which different experiences had already been accumulated, especially in meteo/climate and early warning (Victoria 2008; Ziervogel and Opere 2010; Fabiyi et al. 2012; Masinde et al. 2012). To follow-up on this recommendation, it is necessary to recognize the fields that are best investigated using participatory methods (mobilization of communities in hazard identification and in the organization of bottom-up responses) and those better suited to scientific-technical investigation (risk level, hazard probability, scenarios, potential damages, measures identification residual risk) to allow not only greater efficiency but also the up-scaling of local information for the purposes of policy monitoring (e.g.: sustainable development goals 11 and 13) and design.

The aim of this chapter is to check whether or not it is possible to improve the community risk assessment according to an encoded definition of risk assessment 


\begin{tabular}{|c|c|c|c|}
\hline \multicolumn{2}{|c|}{ MILA } & \multicolumn{2}{|l|}{ CRA - VCA } \\
\hline \multicolumn{2}{|l|}{ Technique } & Steps & Tools \\
\hline Participated workshop & Hazard identification & - Hazard identification & \\
\hline Satellite images & Hazard prone areas & Vulnerability/capacity assessment & \\
\hline Gage height & & & \\
\hline Rainfall dataset & & & \\
\hline Yield dataset & & & \\
\hline Prices & Potential damages & Risk level & \\
\hline Desk & Risk level- & Risk ranking & Focus group \\
\hline Desk & Risk ranking & Climate change & \\
\hline Model & Future climate & Risk acceptance & \\
\hline Workshop & Risk reduction measures & Risk action & \\
\hline USDA & Residual risk & Risk visioning & \\
\hline Desk & Treatement-Potential damages & Risk reduction measures & \\
\hline Final workshop & Risk acceptance/refusal & & \\
\hline
\end{tabular}

Fig. 11.1 Steps and tools of the MLA and the CRA compared

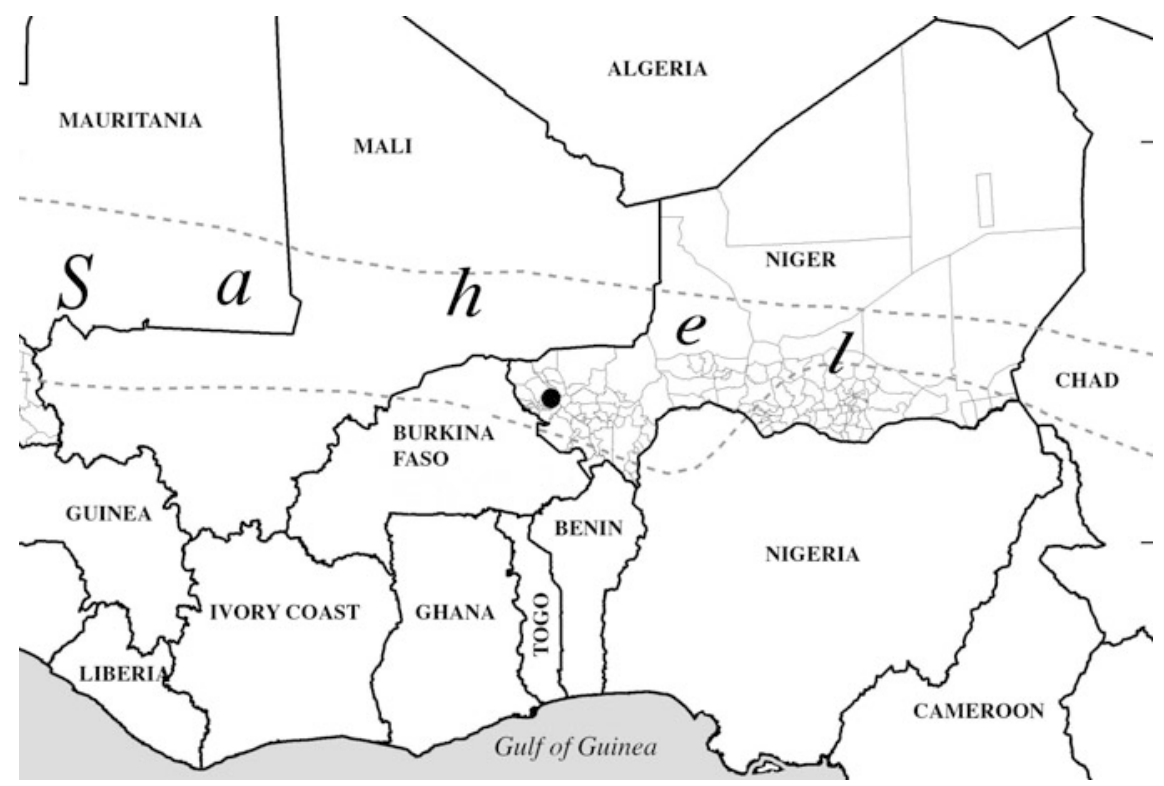

Fig. 11.2 The study area (dot) in Wester Africa context

(ISO 31010), using an integrated information system (local knowledge, remote sensing, information collected on the ground) (Fig. 11.1).

The multi-risk local assessment is carried out in the villages of Garbey Kourou (population 4800, $27 \mathrm{~km}^{2}$ ) and Tallé (population 2700 and $15 \mathrm{~km}^{2}$ ) in the Gothèye municipality, in Niger (Fig. 11.2). The two villages are among those worst hit by river and pluvial flooding in the municipality and are also exposed to agricultural drought. They are two neighbouring administrative villages, situated on the left bank of the Sirba river, just before the confluence with the Niger river, $12 \mathrm{~km}$ from the municipal capital and $60 \mathrm{~km}$ from Niamey, near the Niamey-Burkina Faso national road. 
The method applied starts with the definition of risk as a probability of potential damages. The risk identification is carried out using some tools of the CRA (participated workshop, transect walk, resource mapping, historical disaster profile). The risk analysis is performed with data measured on site by the farmers using rain gauges, data from the meteo station of Gothèye, prices, and remote sensing (peak river flood, land cover, DEM, flood and drought prone areas, climate trends). The risk evaluation involves the definition of risk reduction measures (workshop) in the light of the 2020-50 climate trend (climate downscaling modelling), their potential impact, the calculation of the residual risk and the comparison between risk reduction costs and potential damage costs.

The activity is divided into four parts: methodology, results (presentation of the study area, risk analysis, risk evaluation), discussion, conclusions.

\subsection{Methodology}

A participatory workshop in each village (Fig. 11.3) allowed the identification of the major hazards (pluvial and river flooding, agricultural drought) and the understanding of the characteristics of the receptors via transect walks in hazard prone areas.

The risk $(\mathrm{R})$ is considered to be the product of the probability of a hazard $(\mathrm{H})$ and of the potential damages (D): $R=H^{*} D$. The probability of hazard is the chance of

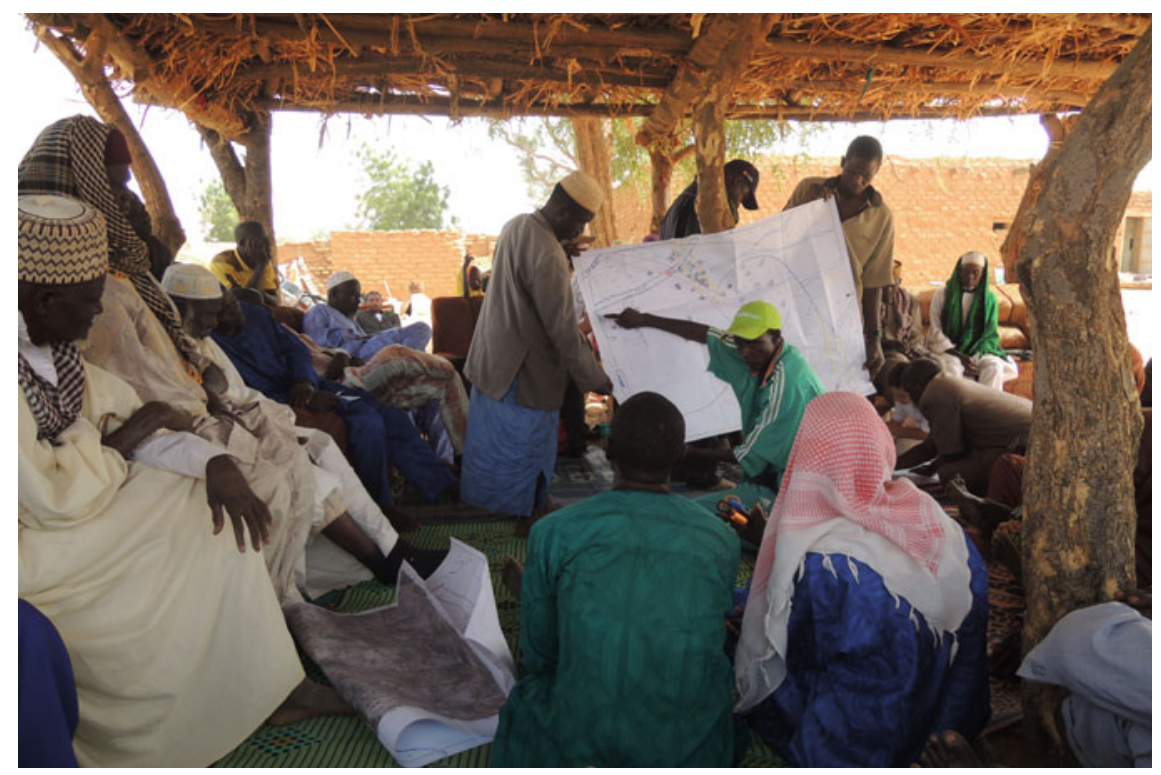

Fig. 11.3 Tallé, November 2014. Flood prone area during the participatory workshop 
occurrence (inverse of the return period) expressed as a number between 0 (impossibility) and 1 (absolute certainty) that critical rain will cause pluvial flooding, that there will be a repeat of the record flood peak of the river Sirba $(531 \mathrm{~cm})$, that there will be a sequence of more than 10 dry days or a wet season of less than 65 days (fatal to millet). On this matter, we must remember that millet has two critical phases: germination and heading-flowering. The lack of water during these phases causes panicle abortion. For cultivars with a cycle that is shorter than 90 days, the critical phase lasts from the 40th to the 10th day before harvesting. For cultivars with a cycle that is longer than 90 days, the phase lasts from the 50th to the 10th day (Edlin 1994: 19). In the daily rainfall dataset of Gothèye, we identified daily total precipitation of up to $2.5 \mathrm{~mm}$, below the daily minimum required by millet (Edlin 1994: 19) and considering the effect of the last rain before a sequence of dry days. The last millimetres of rainfall are divided by the mean value of the daily potential evapotranspiration in the wet season $(6 \mathrm{~mm} /$ day $)$, as calculated in Tillabéri, 54 km north of Garbey Kourou (Sivaakumar et al. 1993). For example, a sequence of 16 consecutive dry days is reduced to 13 due to the $16 \mathrm{~mm}$ that fell the day before the dry spell began. Obviously this is a simplification which does not consider the water that has actually seeped into the ground due to runoff. The receptors have been identified and measured in the area:

- flooded on 11 August 2014, after $40 \mathrm{~mm}$ of rain

- flooded by the river Sirba on 22 August 2012, when the water reached a height of $531 \mathrm{~mm}$ at Garbey Kourou (record flood peak of the last 69 years)

- farmed on 28 August 2014, at the end of one of the worst wet seasons in recent years

The receptors exposed to flooding were identified (Satellite image Stereo WorldView 2014) only within the sub-watersheds to which the two villages belong, because they contain the receptors with the highest value. Those exposed to drought were identified in the watersheds (interpretation of a satellite image at high geometrical resolution) and in the rest of the village lands (estimation).

The flooded zone was obtained by projecting the height corresponding to the $531 \mathrm{~cm}$ recorded at the gauge height in Garbey Kourou (Fig. 11.4) on the DEM obtained from the satellite image ortho-rectified with control points on the ground (satellite 2014).

The cropped area was determined considering that Garbey Kourou and Tallé can still satisfy their yearly cereal needs (YCN) with the village lands alone when the wet season is favourable, like in 2012, when they exceeded $9 \%$. Consequently, the cropped area (CA) in the village lands becomes: $\mathrm{CA}_{\mathrm{GK}+\mathrm{T}}=\left(\mathrm{P}_{2015} * \mathrm{YCN}\right) /$ millet yield.

The potential damages in the event of flooding are the "maximum damages that could occur should a flood eventuate. In assessing potential damages, it is assumed that no actions are taken by the flood-affected population to reduce damage, such as lifting or shifting items to flood-free locations and shifting motor vehicles" (NSWG 2005: 5). The potential damages are calculated as the value of the receptors (houses, garden fences, millet, gombo, oseille, and sesame crops). Depth-damage and 


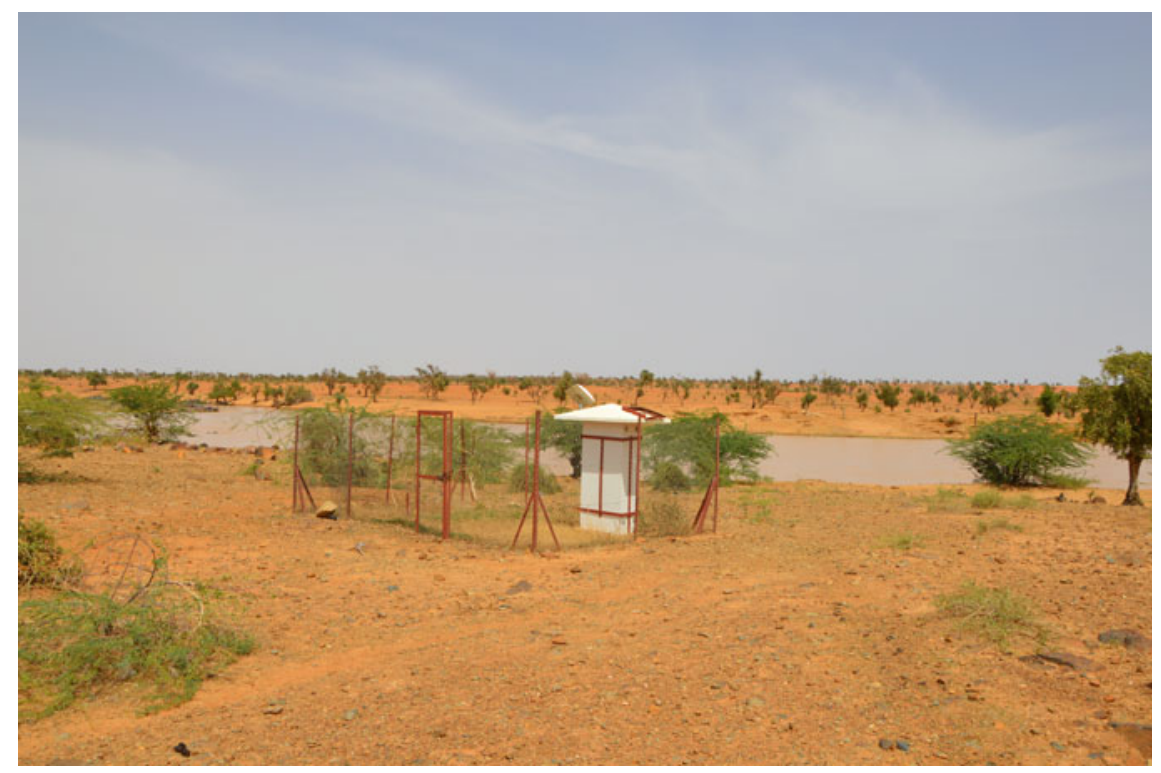

Fig. 11.4 The Sirba hydro station at Garbey Kourou in June 2014

duration-damage curves were not used as all the buildings have walls made of crude earth which collapse as soon as the water crosses the threshold. The indirect effects of flooding are not considered. The value of the receptors is obtained from the cost of every construction element and labour recorded using the price schedule (Zaneidou 2013) and then checked locally.

Drought on the other hand does not cause the complete loss of the harvest. It has been assumed that the maximum cereal deficit of the Department of Gothèye in the last six years $(-53 \%$ in 2011$)$ can be used as the value of unproductive fields in the two villages, assuming that the farms only sow the area necessary to meet their cereal needs. The value of the crop potentially damaged is obtained considering the price of the crop on the market of Gothèye in September 2014 (RN, MCPSP 2014a, b) multiplied by the yield/ha (RN, MF, INS 2013a) and by the rate of unproductive fields.

The risk evaluation requires knowledge of the risk level after the risk treatment (residual risk) and comparison of the cost of the risk treatment with that of potential damages. The residual risk should allow acceptance or refusal of the risk. The risk treatment required the identification of the risk reduction measures in workshops, in the presence of the mayor, the municipal technical services and experts of the ministry of agriculture, CNEDD, DIST-Politecnico di Torino, Ibimet-CNR and the National Directorate for Meteorology. The choice of the measures prioritises the reduction of the receptors, prevention of the installation in hazard prone areas, integration of risk reduction measures with development measures (irrigated 
agriculture) and consistency with the climate (improved seeds, WSC). The National Meteorological Directorate of Niger has performed a specific analysis of the climate change expected to take place by 2025 and by 2050 in the region to which the villages belong (Bacci et al. 2016).

The sizing of the measures was carried out in consideration of the demographic dynamics of the villages revealed in the 3rd and 4th population census (RN, MF, INS 2006, 2014) and climate change.

The expected effect of the WSC measures is calculated using the USDA method (1986) adapted to the local context by Fiorillo and Tarchiani (Chap. 12), assuming that the reduction of the runoff generates an equivalent reduction of damages (e.g.: $30 \%$ of run-off reduction $=30 \%$ of damage reduction).

The sources of information used are a satellite image (Satellite image Stereo WorldView 2014) taken towards the end of the wet season (28 August 2014), the relative DEM with a contour interval of $1 \mathrm{~m}$, the population census 2001 and 2012, the river daily discharge and gauge height between 1956 and 2014 (Ministère de l'hydraulique et de l'assainissement, hydrological forecasting system for the Niger river basin), the daily rainfall recorded in Gothèye between 1954 and 2014 and in the two villages in 2012 and in 2014 (Direction de la Météorologie Nationale), the prices of construction materials and of the works, as shown in the price schedules (RN, MDA unknown; Zaneidou 2013), those of crops (RN, MCPSP, SIMA 2014a, b) and relative yields (RN, MF, INS 2014).

\subsection{Results}

\subsubsection{Study Area}

Gothèye municipality administers an area of $3600 \mathrm{~km}^{2}$ delimited by the rivers Niger, in the east, and Sirba to the south. Just 7500 people live in the municipal capital, 85,000 are distributed in 25 administrative villages and 121 hamlets.

Garbey Kourou (population 4800) and Tallé (population 2700) are among the biggest and oldest villages in the Municipality, having been founded in 1301 and 1845 respectively. The two villages lie in a complex of sub-watersheds on a slight slope (about $1 \%$ ) towards the river Sirba, $4 \mathrm{~km}$ from the confluence with the river Niger (Figs. 11.5 and 11.6).

The administrative rank (it is a place where taxes are paid and justice is served), the presence of a health centre, rural radio, the black smith, a welder, a gas station and the weekly market make it the reference point for a vast area. The village lands also stretch along the right bank of the river, in the Namaro municipality, and include some hamlets, used during the wet season to cultivate the fields furthest away. In recent years, the two villages have reached a good level of infrastructure thanks to the construction of numerous boreholes and to the arrival of electricity (Commune de Gothèye 2009). 


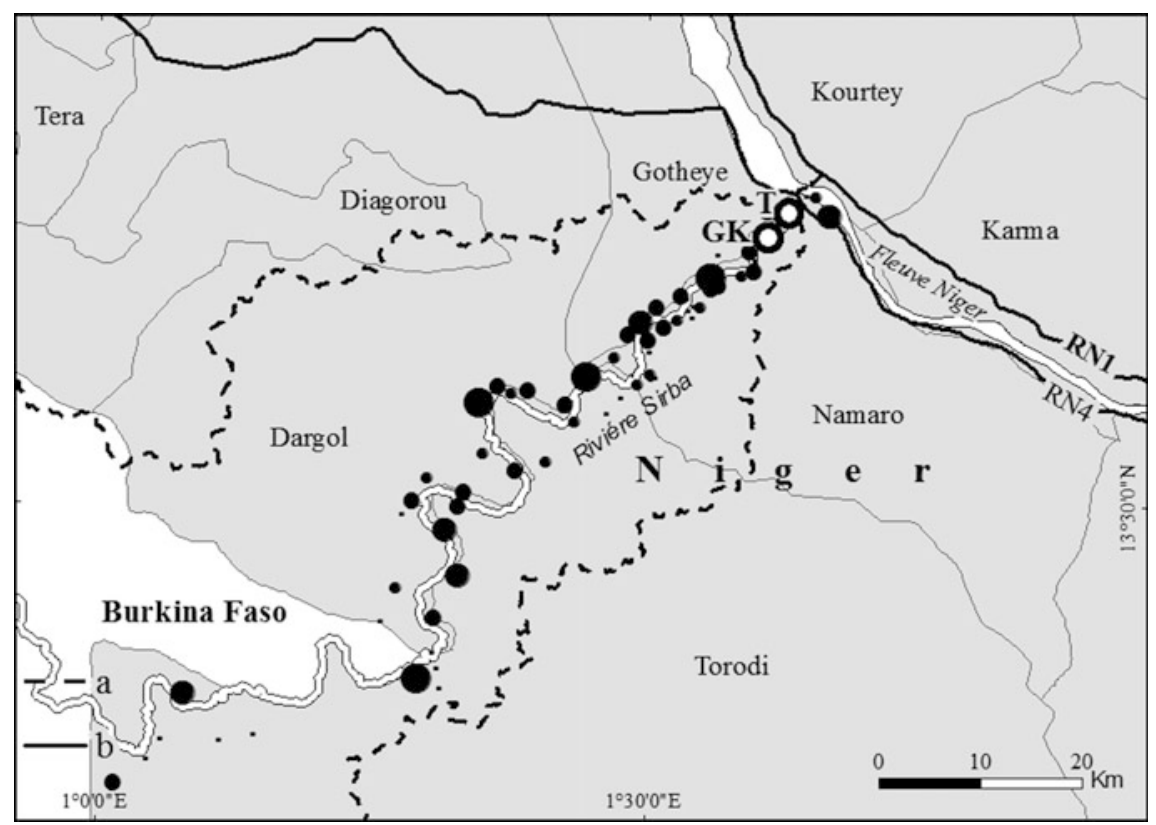

Fig. 11.5 Garbey Kourou (GK) and Tallé (T): Sirba watershed (a), National road n. 4 (b)

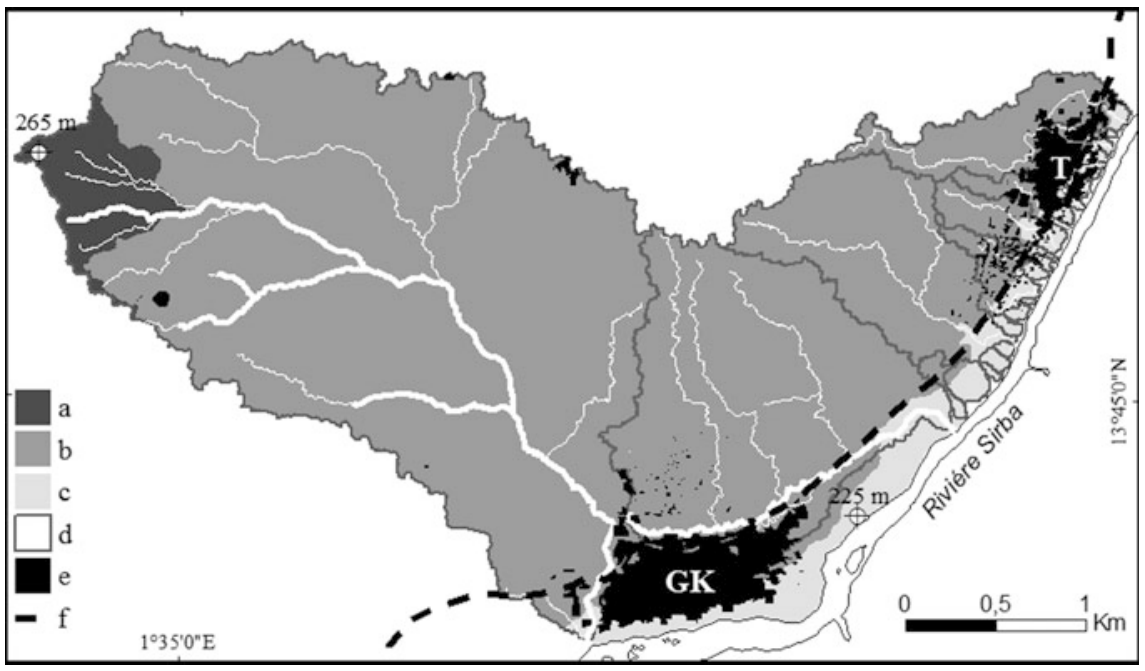

Fig. 11.6 The morphology of the Garbey Kourou (GK) and Tallé (T) sub-watersheds, 2015: glaze (a), lower glaze (b), valley bottom (c), sub watersheds boundaries (d), built-up (e), laterite track (f) 
Table 11.1 Demographic trends for Garbey Kourou and Tallé, 2001-2022

\begin{tabular}{l|l|l|l|l|l|l|l|l}
\hline Village & Gender & 2001 & $\mathrm{r}_{2001-12}$ & 2012 & $\mathrm{r}_{2012-15}$ & 2015 & $\mathrm{r}_{2015-22}$ & 2022 \\
\hline \multirow{2}{*}{$\begin{array}{l}\text { Garbey } \\
\text { Kourou }\end{array}$} & $\mathrm{MF}$ & 3990 & 1.36 & 4634 & 1.36 & 4827 & 1.36 & 5382 \\
\cline { 2 - 9 } & $\mathrm{H}$ & 488 & & 520 & & 542 & & 597 \\
\cline { 2 - 9 } Tallé & $\mathrm{MF} / \mathrm{H}$ & 8.2 & & 8.9 & & 8.9 & & 8.9 \\
\cline { 2 - 9 } & $\mathrm{MF}$ & 2235 & 1.39 & 2603 & 1.39 & 2713 & 1.39 & 2990 \\
\cline { 2 - 9 } & $\mathrm{H}$ & 273 & & 345 & & 360 & & 396 \\
\cline { 2 - 9 } & MF/H & 8.2 & & 7.5 & & 7.5 & & 7.5 \\
\hline
\end{tabular}

$F$ Females, $H$ Households, $M$ Males, $r$ Annual variation rate Sources RN, MF, ISN 2006, 2014

In Niger, a wet season of 90 days allows millet and sorghum rain-fed crops to grow. Sometimes the wet season is shorter and, more and more often, there are long gaps between rains, reducing the crop yield. To compensate for losses, the farmers practice irrigated crops during the dry season (November-May). Garbey Kourou is a pioneer centre of female associations for the irrigated production of gombo, oseille, paprika and sesame (Hadizatou 2012), which spread from this village to its neighbours about twenty years ago.

This is why the rural radio, which played an important role in spreading this practice, broadcasts from Garbey Kourou.

The demographic growth (1.37\% annually between 2001 and 2012) and the slight reduction in the dimension of households (Table 11.1) have led to increased demand for land and for wood to burn, a reduction in tree coverage to less than 12 trees/ha (Acacias, Balanites aegyptiaca and Ziziphus mauritiana), the abandon of fallow lands with higher agricultural potential and the cultivation of lands used exclusively for grazing. Households keep goats and sheep in the village, sending cattle in transhumance during the wet season and bringing them back in after threshing to feed on crop residues.

\subsubsection{Risk Identification}

A participated workshop in each of the two villages has allowed the identification of three main hazards: pluvial flooding, river flooding, agricultural drought (Fig. 11.3). The causes of flooding are numerous: (i) changed rainfall pattern (climate change), (ii) opening of the dams in Burkina Faso during heavy rainfall, (iii) deterioration of the river banks due to the extraction of clay from the sides to produce bricks, (iv) sanding up of the riverbeds due to erosion triggered by deforestation. In the case of river flooding, the damages are due to the settlement in flood prone areas of households that cannot find safer sites at low cost. The cause of pluvial flooding is the deterioration of works for water and soil conservation-WSC upstream, which can no longer encourage the infiltration of rain water and reduce the runoff. 


\subsubsection{Risk Analysis}

The drought prone areas are fields planted with crops at 28 August 2014: 353 ha (satellite image interpretation) in the sub-watersheds and 2500 ha (estimated) in the village lands of Garbey Kourou and Tallé. $40 \mathrm{~mm}$ of rain is $79 \%$ likely to fall in 2015. A river flood of $531 \mathrm{~cm}$ has a $1.6 \%$ likelihood of occurrence in 2015.

An agricultural drought is $13 \%$ likely to last eleven consecutive days (as in 2006 ) in 2015 , and there is a $6 \%$ probability of having a wet season lasting less than 65 days and a $1.6 \%$ probability of having 16 consecutive dry days in 2015 .

In the sub-watersheds considered, there are houses made fully from crude earth, roofed with corrugated metal sheets, with fenced gardens, millet, sorghum, gombo, oseille, and sesame fields. Despite being small and made of crude earth, the buildings make up the highest exposed value, considering the same surface area (Table 11.2; Fig. 11.7). In the event of drought, on the other hand, the crops have

Table 11.2 Potential damages at Garbey Kourou and at Tallé in 2015

\begin{tabular}{l|l|l|l}
\hline Village hazard & Hazard prone quantity & Unit value & Total \\
\hline Receptor & n. & FCFA & $\begin{array}{l}\text { M } \\
\text { FCFA }\end{array}$ \\
\hline
\end{tabular}

Garbey Kourou

\begin{tabular}{l|l|r|r}
\hline River flood & & & 79.3 \\
\hline Crude earth house $33 \mathrm{~m}^{2}$ & 79 & 953,375 & 75.3 \\
\hline Improved crude earth house $33 \mathrm{~m}^{2}$ & 2 & $1,365,175$ & 2.7 \\
\hline Garden fence & 2 & 640,000 & 1.3 \\
\hline Pluvial flood & & & 29.8 \\
\hline Crude earth house $41 \mathrm{~m}^{2}$ & 22 & $1,201,890$ & 26.4 \\
\hline Improved crude earth house $41 \mathrm{~m}^{2}$ & 2 & $1,696,126$ & 3.4 \\
\hline Drought, watershed & & & 26.2 \\
\hline Millet, ha & $(347 * 547) * 53 / 100$ & 250,000 & 25.1 \\
\hline Gombo, oseille, sesame, ha & $(6 *) 53 / 100$ & 349,000 & 1.1 \\
\hline Drought, all village lands & & & 147.7 \\
\hline Millet, ha & $(4827 * 231) * 53 / 100$ & 250,000 & 147.7 \\
\hline Gombo, oseille, sésame, ha & $(6) * 53 / 100$ & 349,000 & 1.1 \\
\hline Total, sub-watershed & & & 135.4 \\
\hline Total, all village lands & & & 257.9 \\
\hline
\end{tabular}

Tallé

\begin{tabular}{l|l|l|c}
\hline River flood & & & 59.7 \\
\hline Crude earth house $27 \mathrm{~m}^{2}$ & $38 * \ldots$ & & 56.4 \\
\hline Improved crude earth house $27 \mathrm{~m}^{2}$ & $2 * \ldots$ & & 3.5 \\
\hline Garden fence & $164 * \ldots$ & & 0.3 \\
\hline Drought, sub-watershed & & & 7.8 \\
\hline
\end{tabular}


Table 11.2 (continued)

\begin{tabular}{l|l|c|c}
\hline Village hazard & Hazard prone quantity & Unit value & Total \\
\hline Millet, ha & $(75 * 547) * 53 / 100$ & 250,000 & 5.4 \\
\hline Gombo, oseille, sesame, ha & $(13) * 53 / 100$ & 349,000 & 2.4 \\
\hline Drought, all village lands & & & 83.0 \\
\hline Millet, ha & $(2713 * 231 * 250) * 53 / 100$ & & 83.0 \\
\hline Gombo, oseille, sesame, ha & $(13 * 349,000) * 53 / 100$ & & 2.4 \\
\hline Total sub-watersheds & & & 67.5 \\
\hline Total all village lands & & & 145.1 \\
\hline
\end{tabular}

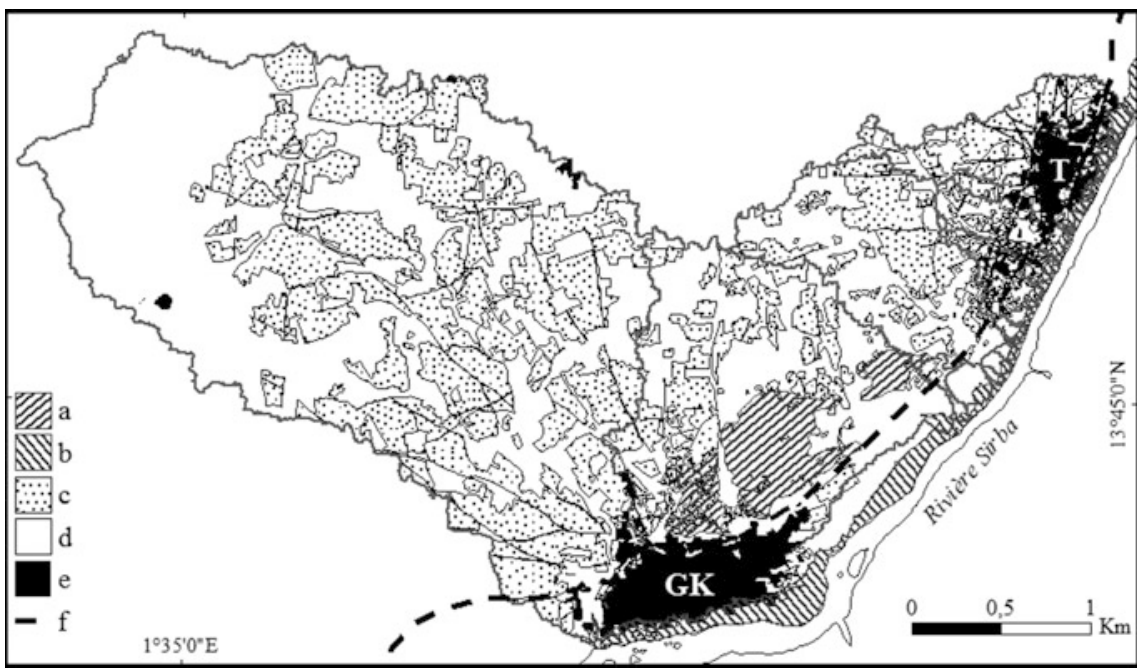

Fig. 11.7 Garbey Kourou and Tallé sub watersheds, 28 August 2014. Pluvial flood prone area (a), river flood prone area (b), agricultural drought prone area (c), sub-watershed limits (d), built up area (e), laterite track (f)

the highest exposed value. The 4827 residents of Garbey Kourou annually consume $231 \mathrm{~kg}$ of cereals per head (millet, sorghum, maize, fonio and rice) and, consequently, require 1000 tons (RN, MA, DS 2013). The worst drought (2011) in the last five years reduced production in the Department to 53\%. If the same level of drought was to occur in Garbey Kourou too, the damages would amount to 500 tons which, at a price of 250,000 FCFA/ton, would have a value of 148 million FCFA, while in the sub-watersheds alone it would amount to 25 million FCFA. Similarly, the 2713 residents of Tallé require 627 tons, and drought could reduce the yield to 332 tons with damages amounting to 83 million FCFA (Table 11.2).

In Garbey Kourou (all village lands), pluvial flood risk is easily in first place, followed by drought risk and river flood risk. This result is obtained from a much 
Table 11.3 Risk level at Garbey Kourou and at Tallé in 2015

\begin{tabular}{|c|c|c|c|c|}
\hline Village hazard & Probability & $\mathrm{H}(\%)$ & $\mathrm{D}$ (FCFA) & $\mathrm{R}=\mathrm{H} * \mathrm{D}(\mathrm{M}$ FCFA) \\
\hline \multicolumn{5}{|l|}{ Garbey Коurou } \\
\hline River flood & Medium & 0.02 & 79.3 & 1.6 \\
\hline Pluvial flood & High & 0.79 & 29.8 & 23.5 \\
\hline Drought sub-watershed & High & $0.13-0.06$ & 26.2 & 3.4 \\
\hline Drought all village lands & High & $0.13-0.06$ & 147.7 & 19.2 \\
\hline Total all village lands & & & & 44.3 \\
\hline \multicolumn{5}{|l|}{ Tallé } \\
\hline Drought sub-watershed & High & 0.13 & 7.8 & 1.0 \\
\hline Drought all village lands & High & 0.13 & 83.0 & 10.8 \\
\hline Flood & Medium & 0.02 & 59.7 & 1.2 \\
\hline Total all village lands & & & 0.89 & 12.0 \\
\hline
\end{tabular}

Table 11.4 Risk ranking at Garbey Kourou and at Tallé in 2015

\begin{tabular}{|c|c|c|}
\hline \multirow{2}{*}{$\begin{array}{l}\text { Village } \\
\text { Risk }\end{array}$} & \multicolumn{2}{|l|}{ Probability } \\
\hline & High (M FCFA) & Medium (M FCFA) \\
\hline \multicolumn{3}{|l|}{ Garbey Kourou } \\
\hline Pluvial flood & 33.5 & - \\
\hline Drought all village lands & 3.4 & \\
\hline Drought sub-watersheds & 19.2 & 0.79 \\
\hline River flood & - & 1.6 \\
\hline \multicolumn{3}{|l|}{ Tallé } \\
\hline Drought all village lands & 10.8 & \\
\hline River flood & - & 1.2 \\
\hline Drought sub-watersheds & 1.0 & 0.10 \\
\hline
\end{tabular}

higher probability of occurrence of $40 \mathrm{~mm}$ rain than 11 consecutive days or compared to a flood of $531 \mathrm{~cm}$ (Table 11.3). In Tallé, on the other hand, drought risk is in first place, followed by river flood, if all the village lands are considered (Table 11.4).

\subsubsection{Risk Evaluation}

The evaluation requires knowledge of the cost and expected impact of the risk treatment on the current risk level, and comparison of the cost of potential damages before risk treatment with those of the treatment itself.

Twenty measures have been identified for Garbey Kourou and 14 for Tallé. The measures for pluvial flooding are the management of gullies, new WSC, existing WSC maintenance, installation of a gauge in the pond, pond drainage, a ridge 


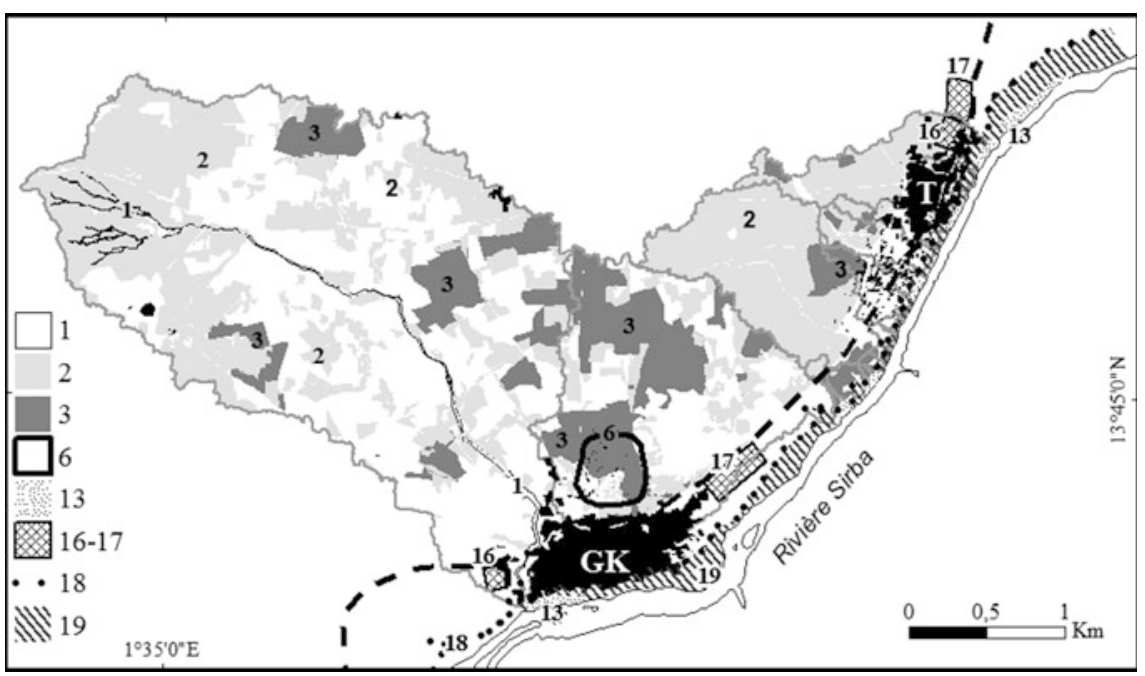

Fig. 11.8 Localisation of the measures of risk treatement at Garbey Kourou and at Tallé (numbers according Table 11.5)

(levee) around scattered houses in the pond, protected wells, retrofitting of crude earth construction, raised latrines (EAA 2012). Drought risk reduction measures are: seasonal forecasts, short cycle millet cultivar (Miko 2013), further development of irrigated crops (RN, CRAT 2012), pond management for fish breeding (Fermont 2013), livestock food banks. The river flood risk reduction measures consist in resettlement of the households currently settled in flood prone areas, prevention of further installations in the flood prone area by making building plots available in relation to the demographic dynamics of the two villages, flood prone area delimitation, land use regulation for the flood prone area, early flood warning system (Fig. 11.8; Table 11.5). The measures of WSC (trapezoidal bunds, zaii, contour stone bunding, semi-circular hoops) (BMZ 2012) are defined in relation to the type of soil (rocky, laterite, sandy, etc.), and irrigated gardens are sized to satisfy $10 \%$ of households. The unitary cost of these measures is determined on the basis of that sustained by the SEMAFO Foundation (2014) to create similar measures in the two villages, or consulting the price schedules available (RN, MDA unknown; Zaneidou 2013). This has made it possible to estimate a risk treatment cost of 101 million FCFA for Garbey Kourou (all village lands) and of 40 million FCFA for Tallé (sub-watershed only). These measures are consistent with the results of the climate change analysis in the Tillabéri region, which envisages a considerable inter-annual variability in total rainfall by 2025 , an increase in minimum and maximum temperatures $\left(+0.8\right.$ and $\left.+1{ }^{\circ} \mathrm{C}\right)$, a tendency to extend the farming season until the end of October-beginning of November, and drier conditions, with poor distribution of rainfall in phases when crops are vulnerable, suggesting the use of more drought-resistant cultivars, despite the fact that these are less productive (Bacci and Gaptia Lawan 2016: 115, Bacci et al. 2017). 
Table 11.5 Risk treatement measures at Garbey Kourou and Tallé

\begin{tabular}{|c|c|c|c|}
\hline Hazard & Risk reduction measure & GK & $\mathrm{T}$ \\
\hline \multirow[t]{9}{*}{ Pluvial flood } & 1. Gully treatment & $\bullet$ & \\
\hline & 2. WSC new & $\bullet$ & $\bullet$ \\
\hline & 3. WSC existent/maintenance & $\bullet$ & \\
\hline & 4. Flood gauge in the pond & $\bullet$ & \\
\hline & 5. Pond drainage & $\bullet$ & \\
\hline & 6. Ridge to protect settlement & $\bullet$ & \\
\hline & 7. Boreholes protection & $\bullet$ & \\
\hline & 8. Earth houses retrofitting & $\bullet$ & \\
\hline & 9. Raised latrines & $\bullet$ & $\bullet$ \\
\hline \multirow[t]{6}{*}{ Drought } & 10. Seasonal forecasts & $\bullet$ & $\bullet$ \\
\hline & 11. Improved seeds & $\bullet$ & $\bullet$ \\
\hline & 12. Technological set & $\bullet$ & $\bullet$ \\
\hline & 13. Irrigated crops extension & $\bullet$ & $\bullet$ \\
\hline & 14. Pond management for fishing & $\bullet$ & \\
\hline & 15. Livestock food banks & $\bullet$ & $\bullet$ \\
\hline \multirow[t]{5}{*}{ River flood } & 16. Resettlement of the population living in flood prone areas & $\bullet$ & $\bullet$ \\
\hline & 17. Avoiding reinstallation in flood prone areas & $\bullet$ & $\bullet$ \\
\hline & 18. Trees planting along the river flood prone area & $\bullet$ & $\bullet$ \\
\hline & 19. Regulation for the flood prone area & $\bullet$ & $\bullet$ \\
\hline & 20. Early warning river flood & $\bullet$ & • \\
\hline
\end{tabular}

To estimate the residual risk, we assumed that (i) the adoption of short cycle cultivars would reduce losses in the event of drought by $50 \%$, also considering the lower yield compared to long cycle cultivars; (ii) the households that practice irrigated agriculture (10\%) fully compensate for any losses of rain-fed crops with sales of the products of irrigated agriculture.

This said, in Garbey Kourou, the residual risk would fall to 6\% (sub-watersheds) and to $17 \%$ (all village lands) of the 2015 risk level. In Tallé, on the other hand, it would fall to $23 \%$ (sub-watersheds) and to $41 \%$ (all village lands) (Table 11.6).

The cost of the treatment equates to $34 \%$ of the potential damages in Garbey Kourou and $28 \%$ in Tallé (Table 11.7).

\subsection{Discussion}

The aim of this chapter was to check the feasibility of the Multirisk Local Assessment-MLA carried out with the integration of local and scientific-technical knowledge in a context of climate change to improve current Community Risk 
Table 11.6 Residual risk at Garbey Kourou and at Tallé, 2018 (* improved seeds (50\%) + irrigated crops $(10 \%)$

\begin{tabular}{|c|c|c|c|c|c|}
\hline \multirow{2}{*}{$\begin{array}{l}\text { Village } \\
\text { Hazard }\end{array}$} & \multirow{2}{*}{$\begin{array}{l}\text { Risk } \\
\text { MFCFA }\end{array}$} & \multicolumn{2}{|c|}{ Damages reduction } & \multicolumn{2}{|c|}{ Residual risk } \\
\hline & & $\%$ & MFCFA & MFCFA & $\%$ \\
\hline \multicolumn{6}{|l|}{ Garbey Коигои } \\
\hline Pluvial flood & 23.5 & 100 & 23.5 & 0 & \\
\hline Drought sub-watershed & 3.4 & 50 & 1.7 & 1.7 & \\
\hline Drought all village lands & 19.2 & 60 & 11.5 & 7.7 & \\
\hline River flood & 1.6 & 98 & 1.6 & 0.0 & \\
\hline Total sub-watershed & 28.5 & - & 26.8 & 1.7 & 6 \\
\hline Total all village lands & 44.3 & - & 36.6 & 7.7 & 17 \\
\hline \multicolumn{6}{|l|}{ Tallé } \\
\hline Drought sub-watershed & 1.0 & 50 & 0.5 & 0,5 & \\
\hline Drought all village lands & 10.8 & 60 & 6.5 & 4.2 & \\
\hline River flood & 1.2 & 98 & 1.2 & 0.0 & \\
\hline Total sub-watersheds & 2.2 & & 1.7 & 0.5 & 23 \\
\hline Total all village lands & 13.0 & & 7.7 & 5.3 & 41 \\
\hline
\end{tabular}

Table 11.7 Garbey Kourou and Tallé. Risk reduction costs and potential damages

\begin{tabular}{l|l|l|l}
\hline & $\mathrm{a}$ & $\mathrm{b}$ & $\mathrm{a}-\mathrm{b}$ \\
\hline Village & Treatement & Potential damages & $\Delta$ \\
Hazard & M FCFA & M FCFA & M FCFA \\
\hline
\end{tabular}

Garbey Kourou

\begin{tabular}{l|l|l|l}
\hline Pluvial flood & 67 & 30 & -37 \\
\hline Drought sub-watershed & 16 & $26^{*}$ & 10 \\
\hline Drought all village lands & - & 148 & \\
\hline River flood & 18 & 79 & 61 \\
\hline Total sub-watersheds & 101 & 135 & 34 \\
\hline Total sub-watershed/inhabitant & 0.021934 & - & - \\
\hline
\end{tabular}

Tallé

\begin{tabular}{l|l|l|l}
\hline Drought sub-watershed & 15 & 8 & 8 \\
\hline Drought all village lands & - & 83 & - \\
\hline River flood & 25 & 60 & 35 \\
\hline Total sub-watershed & 40 & 68 & 28 \\
\hline Total all village land & - & 143 & - \\
\hline Total sub-watershed/inhabitant & 0.015275 & - & - \\
\hline
\end{tabular}

Assessment practices. The aim was triggered by the weaknesses found in the CRA in large communities, as Nigerien villages often are, and by the recommendations that emerged from the African platform for DRR (2013), WMO (2014) and Sendai conference on DRR (2015). 
We flanked some tools of the CRA based on local knowledge (participated workshop, hazard and resource mapping, historical disaster profile, transect walk) with modern techniques (climate statistical downscaling modelling, hazard probability, potential damage, residual risk). This approach enabled:

- risk ranking based on hazard probability (pluvial and river flood, agricultural drought) to generate potential damages

- comparison of the risk level and ranking between different villages

- identification of risk reduction measures consistent with the local climate change trends at 2025 and 2050

- the decision to accept or refuse the risk, based on the results of residual risk and the comparison between risk reduction costs and potential damage costs.

The analysis produced unexpected results in the risk ranking and the evaluation reached unexpected results with regard to the convenience of risk reduction.

As far as suggestions for future research are concerned, the feasibility check on the MLA proposed in this chapter needs to be extended to a whole municipality (usually made up of dozens and dozens of villages).

\subsection{Conclusions}

This chapter has proven the feasibility and advantages of the MLA. We have verified the method in two adjacent villages, which are among those with the highest populations (7500 residents) along the river Sirba. Despite the two villages being next to one another, the risk ranking is very different: with pluvial flooding in first place in one and drought in the other.

The creation of known measures in the region would allow the reduction of the residual risk to $17 \%$ in Garbey Kourou and to $41 \%$ of the current risk in Tallé. Such a high reduction of the risk would require expenditure equating to just $34 \%$ of the potential damages in Garbey Kourou and $28 \%$ in Tallé: useful information which the VCA would not have supplied. This information also enables an understanding that the cost cannot be sustained with local resources only. It amounts to 22,000 FCFA per head in Garbey Kourou and 15,000 FCFA per head in Tallé. Every household would need to contribute 196,000 FCFA (65,000 FCFA/year) in Garbey Kourou, and 112,000 (37,000 FCFA/year) in Tallé, over a period of three years (the duration of the treatment). While this accounts for just 7 and $13 \%$ of the annual household income $(504,000$ FCFA), this would be enough to take the households too close to the 384,000 FCFA considered to be the food insecurity threshold in Niger (RN, INS, SAP 2012: 24).

In the absence of measures to introduce micro finance, the support of the government and so-called development partners is required.

At this point, there are four issues to look at. 
- Perennial implementation of the risk treatment. The risk treatment is not permanent. The works require annual maintenance and renovation every 10 or 20 years. In the long term, the villages could do without outside help if they were to continue investing in commercial crops.

- Reproducibility of the MLA. The methodology can be re-proposed in municipalities at greatest risk (Tiepolo and Braccio 2016b) and, within these, in the bigger villages, as it is there that we find the receptors of higher value, which justify the costs of risk treatment. In the Tillabéri region, the second most exposed in Niger, there are 24 such villages, and about 140 in the whole country.

- Convenience of the LMA. The assessment allows the formulation of detailed risk treatment plans which would increase the impact of the measures.

- Who should develop the MLA. The NGOs which drew up the first generation local development plans ten years ago and are now busy drawing up the second generation could benefit from specific training and be supported by regional services (determination of the village lands boundaries, hazard prone areas, calculation of the hazard probability).

\section{References}

Abarquez, I., and Z. Murshed. 2004. Community-based disaster risk management. Field practitioners' handbook. Bangkok: Asia disaster preparedness center.

Bacci, M., and M. Mouhaimouni. 2017. Hazard events characterization in Tillaberi region: present and future projection. In Renewing climate planning to face climate changing in the Tropics, ed. M. Tiepolo, E. Pezzoli, and V. Tarchiani. Springer.

Bacci, M., K. Gaptia Lawan, and M. Moussa. 2016. Le climat de la région Tillabéri. In Risque et adaptation climatique dans la région Tillabéri, Niger, ed. V. Tarchiani, and M. Tiepolo, 79-98. Paris: L'Harmattan.

Bacci, M., and K. Gaptia Lawan. 2016. Variabilités et changements climatiques et leurs impacts sur les cultures pluviales dans la région Tillabéri, Niger. In Risque et adaptation climatique dans la région Tillabéri, Niger, ed. V. Tarchiani, and M. Tiepolo, 99-116. Paris: L'Harmattan.

BMZ. 2012. Bonnes pratiques de CES/DRS. Contribution à l'adaptation au changement climatique et à la résilience des producteurs. Les expériences de quelques projets au Sahel. GIZ.

Chambers. R. 1992. Rural appraisal: rapid, relaxed and participatory. IDS Discussion Paper 311.

Commune de Gothèye. 2009. Plan de développement communal 2009-2012.

EAA. 2012. Étude sur l'assainissement productif Ecosan au Niger. Bilan et perspectives. Rapport définitif, avril.

Edlin, M. 1994. Analyse des risques de déficit hydrique au cours des différentes phases phénologiques du mil précoce au Niger. Conséquences agronomiques. In Bilan hydrique agricole et sécheresse en Afrique Tropicale, eds. F.-N. Reyniers, and L. Netoyo, 17-30. Paris: John Libbey Eurotexts.

Fabiyi, O.O. et al. 2012. Integrative approach of indigenous knowledge and scientific methods for flood risk anayses, responses and adaptation in rural coastal communities in Nigeria. Final report for 2011 start grants for global change research in Africa.

Faling, W., J.W.N. Tempelhoff, and D. van Niekerk. 2012. Retoric or action: are South African municipalities planning for climate change? Development Southern Africa 29 (2): 241-257. 
Fermont, Y. 2013. La pisciculture de subsistance en étangs en Afrique: Manuel technique. ACF-International Network.

Florano, E.R. 2015. Mainstreaming integrated climate change adaptation and disaster risk reduction in local development plans in the Philippines. In Handbook of climate change adaptation, ed. W. Leal Filho, 433-456. Springer. doi:10.1007/978-3-642-38670-1_36.

Fondation SEMAFO. 2014. Rapport annuel 2013-2014.

GoN-Government of Nepal. 2011. National framework on local adaptation plans for action. Ministry of science technology and environment.

Guardiola, L., J. Quiñónez, M. Domínguez, N. Jover, and R. Bernol. 2013. Guía metodológica para incorporar la adaptacion al cambio climático en la planificación del dresarollo. Tegucigalpa.

Hadizatou Alhassoumi. 2012. Dynamiques associatives et processus d'affirmation des femmes de Garbey Kourou (Ouest du Niger) atour des activités agricoles. In Genre \& agriculture familiale \& paysanne. Regards Nord-Sud, colloque international Toulouse-Le Mirail, 22-24 Mai 2012.

IFRCRC-International Federation of Red Cross and Red Crescent Societies. 2014. Integrating climate change and urban risks into the VCA. Geneva, IFRCRC: Ensure effective participatory analysis and enhanced community action.

IFRCRC-International Federation of Red Cross and Red Crescent Societies. 2006. What is VCA? An introduction to vulnerability and capacity assessment. Geneva: IFRCRC.

ISO-International Organization for Standardization. 2009. Guide 73:2009. Risk Management Vocabulary.

Masinde, M., and A. Bagula. 2012. ITIKI: bridge between African indigenous knowledge and modern science of drought prediction. Knowledge Management for Development Journal 7 (3): 274-290. doi:10.1080/19474199.2012.683444.

Miko, I. 2013. Multiplication et diffusion de semences de qualité des variétés améliorées et adaptées au changement climatique. Fiche de bonne pratique. Niamey: FAO.

NSWG-New South Wales Government. 2005. Floodplain development manual. Appendix $M-$ Flood damage.

Pezzoli, A., and E. Ponte. 2016. Vulnerability and resilience to drought in the Chaco, Paraguay. In Planning to cope with tropical and subtropical climate change, eds. M. Tiepolo, E. Ponte, and E. Cristofori, 63-88. Berlin: De Gruyter Open. doi:10.1515/9783110480795-005.

Ponte, E. 2014. Flood risk due to heavy rains and rising sea levels in the municipality of Maputo. In Climate change vulnerability in Southern African Cities, eds. S. Macchi, and M. Tiepolo, 187-204. Springer.

Rambaldi, G. 2010. Modélisation participative en 3D-Principes directrices et applications. Wageningen: Centre technique de coopération agricole et rurale ACP-UE.

RN, CRAT. 2012. La production du sésame dans la zone de Gothèye: de la culture de consommation à celle commerciale.

RN, MA, DS. 2013-2015. Évaluation des récoltes de la campagne agricole d'hivernage 20122014 et résultats définitifs 2012-2014. Rapport national de synthèse.

RN, MCPSP-SIMA. 2014a. Bulletin Mensuel Volet Céréales, 9/14, septembre.

RN, MCPSP-SIMA. 2014b. Bulletin Mensuel Volet Produits de Rente, 60, octobre.

RN, MDA. unknown. Recueil des fiches techniques en gestion des ressources naturelles et de production agro-sylvo-pastorales. PAC-Banque Mondiale.

RN, MF, INS. 2014. Niger. Répertoire national des localités (ReNaLoc), juillet.

RN, MF, INS. 2013. Annuaire statistique 2008-2012. Édition 2013.

RN, MF, INS. 2006. ReNaCom- Répertoire national des communes.

Ruiz Rivera, N., J.M. Casado Izquierdo, and M.T. Sánchez Salazar. 2015. Los atlas de riesgo municipales en México como instrumento de ordenamiento territorial. Investigaciones Géográficas. Boletín del Instituto de Geografía, UNAM 88: 146-162.

Sivaakumar, M.V.K., A. Maidoukia, and R.D. Stern. 1993. Agroclimatologie de l'Afrique de l'Ouest. ICRISAT. 
Tiepolo, M., and S. Braccio. 2016a. Flood risk preliminary mapping in Niamey, Niger. In Planning to cope with tropical and subtropical climate change, eds. M. Tiepolo, E. Ponte, and E. Cristofori, 201-220. Berlin: De Gruyter Open. doi:10.1515/9783110480795-013.

Tiepolo, M., and S. Braccio. 2016b. Flood risk assessment at municipal level in Tillabéri region, Niger. In Planning to cope with tropical and subtropical climate change, eds. M. Tiepolo, E. Ponte, E. Cristofori, 221-242. Warsaw/Berlin: De Gruyter Open. doi:10.1515/ 9783110480795-014.

UN. 2015. Third World Conference on DRR. Sendai framework for disaster risk reduction 2015 2030.

UNDHA-United Nations Department of Humanitarian Affairs. 1994. Yokohama strategy and plan of action for a safer world. Guidelines for natural disaster prevention, preparedness and mitigation. In World conference on natural disaster reduction. Yokohama, Japan 23-27 Mai 1994.

UNISDR-The United Nations Office for Disaster Risk Reduction. 2013. Report of the $4^{\text {th }}$ Africa regional platform on disaster risk reduction 13-15 February 2013. Tanzania: Arusha.

Van Aalst, M.K., T. Cannon, and J. Burton. 2008. Community level adaptation to climate change: The potential role of participatory community risk assessment. Global Environmental Change 18: 165-179. doi:10.1016/j.gloenvcha.2007.06.002 .

Vermaak, J., and D. van Niekerk. 2004. Disaster risk reduction initiatives in South Africa. Development Southern Africa 21 (3): 555-574. doi:10.1080/0376835042000265487.

Victoria, L.P. 2008. Combining indigenous and scientific knowledge in the Dagupan city flood warning system. In Indigenous knowledge for disaster risk reduction. Good practices and lessons learned from experiences in the Asia-Pacific Region, 52-54. UNISDR.

WMO-World Meteorological Organization, GFSC. 2014. Plan de mise en cuvre du cadre mondial pour les services climatiques. Geneve.

Zaneidou, D. 2013. Bordereaux des prix unitaires des principaux investissements réalisés par les projets FIDA au Niger - Capitalisation. Volume 1, FIDA.

Ziervogel, G., and A. Opere (eds.). 2010. Integrating meteorological and indigenous knowledge-based seasonal climate forecasts in the agricultural sector. Ottawa: IDRC.

Satellite image Stereo WorldView-2ID:14AUG28105608-M2AS-053799140010 28 August 2014.

Open Access This chapter is licensed under the terms of the Creative Commons Attribution 4.0 International License (http://creativecommons.org/licenses/by/4.0/), which permits use, sharing, adaptation, distribution and reproduction in any medium or format, as long as you give appropriate credit to the original author(s) and the source, provide a link to the Creative Commons license and indicate if changes were made.

The images or other third party material in this chapter are included in the chapter's Creative Commons license, unless indicated otherwise in a credit line to the material. If material is not included in the chapter's Creative Commons license and your intended use is not permitted by statutory regulation or exceeds the permitted use, you will need to obtain permission directly from the copyright holder.

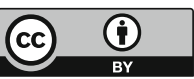

